\title{
Curcumin and Extract of Plantago major, L Increased SPF Value of Cold Cream Base
}

\author{
Nining Sugihartini \\ Faculty of Pharmacy Ahmad Dahlan University \\ J1. Prof. Dr. Soepomo JanturanUmbulharjo Yogyakarta Indonesia \\ Email:irmaningsih75@yahoo.com
}

\begin{abstract}
Octyl methoxycinnamate as the active material of the sunscreen would be degradated after being exposed to the sunlight. Curcumin, rice flour and the extract of Plantago major, $L$ was the material that could function as the sunscreen. The aim of this research was to know the SPF value and the physical characteristics of cream of the sunscreen with the active material octyl methoxycinnamate after the addition of the optimum composition of curcumin and the extract of Plantago major, $\mathrm{L}$ and the optimum composition of rice flour and the extract of Plantago major, $\mathrm{L}$.

In this research three formulas was examined, i.e. the formula I with the active material octyl methoxycinnamate, the formula II with the active material octyl methoxycinnamate and the optimum composition curcumin and the extract of Plantago major, L, Formula III with the active material octyl methoxycinnamate and the optimum composition rice flour and the extract of Plantago major, L. SPF value of each formula was determined by using the Petro method (198I) using UV spectrofotometric method at a $\lambda 290 \mathrm{~nm}-320 \mathrm{~nm}$. The physical characteristics i.e. the power spread, the adhesiveness and the viscosity were also examined analysed with Anova one way at a confidence level 95\%. Result of the research show that SPF value increased after the addition of the optimum composition of curcumin and the extract of Plantago major, L. The physical characteristics of cream of the sunscreen do not change after the addition of the optimum composition curcumin and the extract of Plantago major, $\mathrm{L}$ and the optimum composition rice flour and the extract of Plantago major, L.
\end{abstract}

Key words: Octyl methoxycinnamate curcumin, flour rice, extract of Plantago major, L, sunscreen

\section{INTRODUCTION}

Indonesia is a tropical country with two seasons, the rainy season and dry season. In dry season intensity of the sunlight is very high. The sunlight is really needed by all the living organism for continuation of his life. On the other hand the high intensity of sunlight could result in damage to some human bodies. The part of human body to protect from the effect of the sun light is the layer of skin. Skin could damage if skin get the sunlight in the high intensity in a long time.

To protect skin from the exposure of the sunlight, skin must be covered the material that could prevent direct exposure the sunlight onto skin. Such product is known as sunscreen. Based on the Diffey (2001) user of the sunscreen can reduce the risk of the skin cancer. The mechanism of the sunscreen is absorbing the sunlight and reflecting again the sunlight. Results of the Green research et al. (1999) said that the use of the sunscreen could reduce the probability of the skin cancer.

Plants that often are used in sunscreen are turmeric and rice flour. Turmeric contains curcumin while rice flour contains amilum. Moreover extract of Plantago mayor, L contains antioxidan which is very useful to protect skin from the effect of the free radical (Hertiani, 2000). The compound could increase effectivity of sunscreen based on the value of percent of the transmission eritema and pigmentation (Sugihartini, 2004). Each of this material can be used as the active material of sunscreen.

Black (1990) reported that antioxidan had the potential as photoprotector. The UV light could encourage the formation of free radical compounds in the skin. The compound that had the capacity as antioxidan be able to compete with the target molecule to reduce the damaging effect of the skin. Whereas rice flour that contained amilum could reflect the sun light.

Hadiyanti et al. research (2004) showed that the increasing concentration of curcumin increased the potential of sunscreen with the active material octil methoxycinamat in protecting skin from eritema and pigmentation.

*Corresponding author e-mail : irmaningsih75@yahoo.com 
Nasrudin research (2009) indicated that 30\% rice flour and $70 \%$ extract Plantago major, L is the optimum composition to increase the effectivity of octyl methoxicynamat based on \% transmission of erythema and pigmentation. Sulistiyono research (2009) showed that $80 \%$ curcumin and $20 \%$ extract Plantago major, L was the optimum composition to increase effectivity of octyl methoxicynamat base on $\%$ transmission of erythema and pigmentation

Based on the potential of those three materials, it was important to develop formulation of sunscreen based on SPF parameter to give protection on the skin. SPF was the parameter to determine the effectivity of the sunscreen to protect skin from the exposure of the sunlight. Sunscreen with high value of SPF is expected to give high protection to skin. The sunscreen was made in the cold cream base in order to give comfortability to consumen.

\section{MATERIAL AND METHOD}

\section{Materials and Instrumentation I. Materials}

Rice flour from Beringharjo market, curcumin (Merck), simplisia of Plantago major, L leaf, silica gel $\mathrm{G}$, aquades and aquabides (pharmaceutical grade). Methanol dan ethanol (p.a E.Merck), Whatman paper (no 40).

\section{Instrumentation}

Spectrophotometer UV Vis-1601PC (Shimadzu, Japan), Analitical balance (AR2140 Ohaus, New York), filter (Whatman 0,45 $\mu \mathrm{m}$ nylon), and Sonicator (LC 304, Jerman).

\section{Methode of Research I. Extraction of simplisia of Plantago major, L leaf}

Dry leaves was infundated for 15 minutes at the $90^{\circ} \mathrm{C}$ degree temperature. The filtrate was evaporated with waterbath until thick. Afterthat it was added with ethanol until the solution was not coloured and then was centrifuged. The filtrate was evaporated until almost dry (the ethanolic fraction).

\section{Sample of cream}

Weight of sample was one gram. Table I show composisition of each material in formula. Sample from each formula was getted with procedure :

Firstly $\mathrm{Na}$ Tetraboras solved with aquadest. Others materials (cetaceum, cera alba, paraffin liq) was melted and then mixture with solution of $\mathrm{Na}$ Tetraboras until homogen. Finally curcumin, extract of Plantago major, L and rice flour was added to the each of mixture of the formula according to the each composition.

Table I. Composition of rice flour, curcumin and extract of Plantago major, $L$ in cold cream base

\begin{tabular}{lccc}
\hline Materials & Formula I & Formula II & Formula III \\
\hline Octyl metoxicynamat & $0.5 \mathrm{~g}$ & $0.5 \mathrm{~g}$ & $0.5 \mathrm{~g}$ \\
Rice flour & 0 & $0 \mathrm{~g}$ & $0.15 \mathrm{~g}$ \\
Extract of Plantago major, L & $0 \mathrm{~g}$ & $0.1 \mathrm{~g}$ & $0.35 \mathrm{~g}$ \\
Curcumin & $0 \mathrm{~g}$ & $0.4 \mathrm{~g}$ & $0 \mathrm{~g}$ \\
Cetaceum & $12.5 \mathrm{~g}$ & $12.5 \mathrm{~g}$ & $0 \mathrm{~g}$ \\
Cera alba & $12 \mathrm{~g}$ & $12 \mathrm{~g}$ & $12 \mathrm{~g}$ \\
Paraffinum liq & $56 \mathrm{~g}$ & $56 \mathrm{~g}$ & $56 \mathrm{~g}$ \\
Natrii Tetraboras & $0.5 \mathrm{~g}$ & $0.5 \mathrm{~g}$ & $0.5 \mathrm{~g}$ \\
Aqua Destillata & $18.5 \mathrm{ml}$ & $18 \mathrm{ml}$ & $18 \mathrm{ml}$ \\
\hline
\end{tabular}

Formula I : Sunscreen with active material octyl methoxicynamat

Formula II : : Sunscreen with active material octyl methoxicynamat and optimum composition of extract Plantago major, $\mathrm{L}$ and curcumin

Formula III : Sunscreen with active material octyl methoxicynamat and optimum composition of extract Plantago major, $L$ and rice flour 


\section{Measurement of SPF value}

Sample solved in ethanol and then measurement of SPf value base on Petro method (1981). Absorbance read at $\lambda 290 \mathrm{~nm}-320 \mathrm{~nm}$ with minimal absorbance 0.05. Value of SPF calculated with abbreviation:

$$
\begin{gathered}
\log \mathrm{SPF}=\mathrm{AUC} \times 2 \\
------ \\
\lambda_{\mathrm{n}}-\lambda_{1}
\end{gathered}
$$

Value of SPF calculated with divided area under curve of absorbance at $\lambda$ with difference of highest and lowest of $\lambda$ and then multiply twice. Replication of each formula is 3 .

\section{Evaluation of physical characteristic of sunscreen}

\section{a. Spreadibility test}

Cream $0.5 \mathrm{~g}$ was put on the circle of glass which it was adhered with graphic paper. Cream covered with glass and then 1 gram of load put on it. After 5 menit diameter of spreadibility was noted. Load was added until constant. Spreading of cream was calculated as wide of circle.

\section{b. Adhesivity test}

Cream $0.5 \mathrm{~g}$ was put on dekglass and then cover it with the other dekglass. One $\mathrm{kg}$ of load put on it until 5 minutes and then removed of load. Time to dekglass detached was noted.

\section{c. Viscosity test}

Cream $10 \mathrm{mg}$ was put in cone viscosimeter Brookfield and then viscosity was noted.

\section{Analysis Data}

Data were analysed with Anova one way and continued with $t$ test if there was significant difference at $95 \%$ confidenence level.

\section{RESULTS}

SPF value of octyl methoxycinamat after addition of the optimum composition of rice flour and extract Plantago major, L and optimum composition of curcumin and extract Plantago major, L show in table II.

Data SPF was analysed with Anova one way at $95 \%$ level confidence. Result of analysis show that there is significant difference between formula. Analysis continued with $\mathrm{T}$ test. Result of $\mathrm{T}$ test show in table III.

Result of evaluation of physical characteristic of cream show in table IV. Data of physical characterisyic of cream was analysed with Anova one way at $95 \%$ confidence level. Result of analysis show there was not significant difference between formulas.

\section{DISCUSSION}

\section{A. SPF Value}

This research examined 3 formula. There were Formula I whith the active materials octyl methoxicynamat, Formula II which used octyl methoxicynamat and optimum composition of curcumin and extract Plantago major, L as active materials and Formula III which used octyl methoxicynamat and optimum composition of rice flour and extract Plantago major, L. Protection of sunscreen to skin from exposure of sunlight will increased with addition of these materaials.

Octyl methoxicynamat protect skin from side effect of UV B which it can make sunburn on the skin. Extract of Plantago major, L have maximum absorption in range UV A so it can protect skin from pigmentation. Curcumin as antioxidant protects octyl methoxicinamat from degradation making protection of skin from the side effect of sunlight more longer. Rice flour as sunscreen can reflect sunlight. Octyl methoxicynamat as active material in sunscreen which was added with extract of Plantago major, $\mathrm{L}$, curcumin and rice flour therefore will protect skin more effectively. SPF (Sun Protection Factor) is the parameter to know the potention of sunscreen to protect skin. High value of SPF show the high potention of sunscreen. SPF value of octyl methoxycinamat after addition of the optimum composition of rice flour and extract Plantago major, L and optimum composition of curcumin and extract Plantago major, L show in table II.

Data SPF was analysed with Anova one way at $95 \%$ level confidence. Result of analysis show that there is significant difference between 
Tabel II. SPF value of octyl methoxycinamat after adding of the optimum composition of rice flour and extract Plantago major, $L$ and optimum composition of curcumin and extract Plantago major, $L$

\begin{tabular}{ll}
\hline Formula & SPF Value (X \pm SD) \\
\hline Formula I & $4,8 I \pm 0,7 \mid$ \\
Formula II & $17,65 \pm 5,04$ \\
Formula III & $5,65 \pm 0,95$ \\
\hline
\end{tabular}

Tabel III. Result of T test on SPF value

\begin{tabular}{lcc}
\hline Formula & Significancy \\
\hline Formula I-II & Significant \\
Formula I-III & No Significant \\
Formula II-III & Significant \\
\hline
\end{tabular}

Table IV. Result of evaluation of physical characteristic of cream with active material octyl methoxycinamat after adding of the optimum composition of rice flour and extract Plantago major, $L$ and optimum composition of curcumin and extract Plantago major, $L$

\begin{tabular}{cccc}
\hline Formula & Spreadibility $\left(\mathbf{m m}^{\mathbf{2}}\right)$ & Adhesivity (second) & $\begin{array}{c}\text { Viskosity } \\
\text { (cPoise) }\end{array}$ \\
\hline Formula I & $18.74 \pm 3.55$ & $3.78 \pm 0.65$ & $1517.33 \pm 47.01$ \\
Formula II & $17.11 \pm 0.86$ & $3.60 \pm 0.34$ & $1675.67 \pm 190.12$ \\
Formula III & $13.7 \pm 0.47$ & $3.89 \pm 0.34$ & $1777.67 \pm 83.90$
\end{tabular}

Result of $\mathrm{T}$ test show that there is significant difference between Formula I and Formula II. This may indicated that curcumin and extract Plantago major, L increased capability of octyl methoxicynamat. Curcumin as antioxidant could protect octyl methoxicynamat from degradation because exposure of sunlight so it can protect skin longer. Extract Plantago major, L completed to protect because it have absorption at UV A area and its activity as antioxidant protect octyl methoxicynamat from degradation.

Result of $\mathrm{T}$ test show that there is not significant difference between Formula $\mathrm{I}$ and Formula III. It means that rice flour did not increase capability of octyl methoxicynamat.

Rice flour reflected sunlight so did not effective protect skin. Eventhough in Formula III contain extract Plantago major, L but it can not increase capability of octyl methoxicynamat to protect skin.

Result of $\mathrm{T}$ test show that there is significant difference between Formula II and Formula III. Formula II have the highest value of SPF. It's mean that curcumin increased capability of octyl methoxicynamat more effective than rice flour.

\section{B.Physical characteristic of sunscreen}

Evaluations of physical characteristic of cream were spreadibility, adhesivity and viscosity tests. Spreadibility test show potention of cream to cover skin. Cream would protect skin better if have wider spreadibility. Adhesivity show potention of cream to adhesive on skin. Cream would more protect skin if have longer adhesivity. Viscosity influenced spreadibility and adhesivity of cream. Result of evaluation of physical characteristic of cream show in table IV. 
Data of physical characterisyic of cream was analysed with Anova one way at $95 \%$ confidence level. Result of analysis show there was not significant difference between formulas. This could indicate that optimum composition of curcumin and extract Plantago major, L in Formula II and optimum composition of rice flour and extract Plantago major, L in Formula III did not influence physical characteristic of cream.

Cream in this research used base of Cold cream. This base give cold effect on skin so consumen would feel more comfort.

There is difference in physical characterictic between cream in this research and market. Cream in market have spreadibility 10-20 $\mathrm{cm}^{2}$ and adhesivity 30-240 second. Cream in this research have spreadibility and adhesivity lower than cream in market. This could be due to the higher viscosity of cream in this research.

\section{CONCLUSION}

1. Optimum addition of curcumin and extract of Plantago major, L more effective increased SPF value of cream $(\mathrm{p}<0,05)$.

2. Optimum addition of curcumin and extract Plantago major, $\mathrm{L}$ and optimum composition of rice flour and extract Plantago major, L did not influence physical characteristic of cream.

\section{ACKNOWLEDGMENT}

Thank to Research and Development Institute Ahmad Dahlan University for giving financial support of this research.

\section{REFERENCES}

Black, H.S., 1990, Antioxidant and Carotenoids as Potential Photoprotectants, in Nicholas, J.L., Nadim, A.S., (Eds.), Sunscreens Development, Evaluation and Regulatory Aspect, Vol. 10, 267-273, Marcel Dekker Inc., New York.

Diffey, B., 200I, Sunscreen isn't Enough, J. Photochemistry Photobiology, 64, 105-108.

Green, A., William, G., and Neale, R., 1999, Does Daily Use of Sunscreen or $\beta$-carotene Supplement Prevent Skin Cancer in Healthy Adults?, Lancet, 354, 723-729

Hadiyanty, I.S., Sugihartini, N. and Yuwono, T., 2004, Pengaruh Penambahan Kurkumin Terhadap Fotostabilitas dan Efektivitas Oktil Metoksisinamat Sebagai Bahan Aktif Tabir Surya, Skripsi, Fakulty of Pharmacy, Ahmad Dahlan University, Yogyakarta

Nasrudin, M., Sugihartini, N., and Simbara, A., 2009, Optimasi Komposisi Tepung Beras dan Ekstrak Plantago major, L dengan Metode Simplex Lattice Design Untuk Mendukung Oktil metoksisinamat sebagai Bahan Aktif Tabir Surya, Skripsi, Fakulty of Pharmacy, Ahmad Dahlan University, Yogyakarta

Sugihartini, N., 2004, Pengaruh Penambahan Fraksi Etanol Daun Plantago major L. Terhadap Fotostabilitas dan Efektivitas Oktil Metoksisinamat Sebagai Bahan Aktif Tabir Surya, Tesis, Pascasarjana Program, Gadjah Mada University, Yogyakarta.

Sulistiyono, B., Sugihartini, N. and Simbara, A., 2009, Optimasi Komposisi Tepung Kurkumin dan Ekstrak Plantago major, L dengan Metode Simplex Lattice Design Untuk Mendukung Oktil metoksisinamat sebagai Bahan Aktif Tabir Surya, Skripsi, Fakulty of Pharmacy, Ahmad Dahlan University, Yogyakarta. 